\title{
Accreditation in Higher Education
}

Accreditation is a system for recognizing educational institutions and professional programs affiliated with those institutions for a level of performance, integrity, and quality which entitles them to the confidence of the educational community and the public they serve. In the United States this recognition is extended primarily through nongovernmental, voluntary institutional or professional associations. These groups establish criteria for recognition, arrange site visits, and evaluate those institutions and professional programs that desire recognition status; they approve for recognition those which meet their criteria.

Institutional accreditation is granted by the accrediting commissions of association of schools and colleges, which collectively serve most of the institutions chartered or licensed in the United States and its possessions. These commissions and associations accredit total operating units only.

Specialized accreditation of professional schools and programs is granted by commissions on accreditation set up by national professional organizations in such areas as business, dentistry, engineering, and law. Each of these groups has its distinctive definitions of eligibility, criteria for accreditation, and operating procedures, but all have undertaken accreditation activities, primarily to provide quality assurances concerning the educational preparation of members of the profession.

\section{Uses of Accreditation}

In most other countries the establishment and maintenance of educational standards are the responsibility of a central government bureau. In the United States, however, public authority in education is constitutionally reserved to the states. The system of voluntary nongovernmental evaluation called accreditation has evolved to promote both regional and national approaches to the determination of educational quality.

While accreditation is basically a private, voluntary process, accrediting decisions are used as a consideration in many official actions: federal funding agencies consider accreditation as an important factor in determining eligibility for financial assistance; scholarship commissions and philanthropic foundations frequently limit their grants to accredited institutions or programs of study; employers rely on the accredited status of institutions when evaluating credentials; school counselors use the decisions in advising students about colleges and programs; college and university officials depend on them to assess and award academic credit; and potential students need them for assurance that a college or university has met minimum requirements for educational quality. In addition, these decisions are useful to faculty and staff in their efforts to develop comprehensive educational goals. In many professions, eligibility for certification or licensure is limited to graduates of accredited institutions. Finally, the public is protected from unqualified graduates who may have been inadequately prepared for professional practice.

The accrediting process is also useful in helping institutions maintain high educational standards and improve quality. The accrediting bodies provide counsel to both established and developing institutions and protect them from both external and internal encroachments that might jeopardize their educational effectiveness and academic freedom.

The accrediting process is continuously evolving. The trend has been from quantitative to qualitative criteria, from the early days of simple checklists to an increasing interest and emphasis on measuring the outcomes of educational experiences.

The process begins with the institutional or programmatic selfstudy, a comprehensive effort to measure progress according to previously accepted objectives. The self-study considers the interests of a broad cross-section of constituencies - students, faculty administrators, alumni, trustees, and in some circumstances, the local community. The resulting report is reviewed by the appropriate accrediting commission and serves as the basis for evaluation by a site-visit team from the accrediting group. The site-visit team normally consists of professional educators (faculty and administrators), specialists selected according to the nature of the institution, and members representing specific public interests. The visiting team considers the institution or program according to the dimensions of the self-study and adds judgments based on its own expertise and its external perspective. The evaluation team completes a report, which is reviewed by the institution or program for factual accuracy. The original self-study, the team report and any response the institution or program may wish to make are forwarded to an accreditation review committee. The review body uses these materials as the basis for action regarding the accreditation status of the institution or program. Negative actions may be appealed according to established procedures of the accrediting body.

Accrediting bodies reserve the right to review member institutions or programs at any time for cause. They also reserve the right to review any substantive change, such as an expansion from undergraduate to graduate offerings. In this way accrediting bodies hold their member institutions and programs continually accountable to their educational peers, to the constituencies they serve, and to the public interest.

Historically and currently, accreditation at the postsecondary level may be said to foster excellence in postsecondary education through the development of uniform national criteria and guidelines for assessing educational effectiveness; to encourage improvement through continuous self-study and review; and to assure the educational community, the general public, and other agencies or organizations that an institution or program has clearly defined and appropriate objectives, maintains conditions under which their achievement can reasonably be expected, appears in fact to be accomplishing them substantially, and can be expected to continue to do so.

Accrediting bodies do not rank or grade institutions; they either accredit or decline to accredit them. Most commissions, however, do specify a definite term for which their accreditation is valid, five years usually being the maximum for initial accreditation and ten years for reaccreditation. Many accrediting bodies award candidate status to developing or newly applying institutions, which satisfy eligibility requirements and that present evidence of sound planning, adequate implementation resources, and potential for meeting stated goals within a reasonable period of time. This status, designed for postsecondary institutions and programs that may or may not be fully operational, usually is granted for a two-year term. If progress is being made, candidacy can be extended for up to six years. Institutions or programs that show serious weakness in one or more areas, but which at the same time show firm potential for remedying the deficiencies, may be placed in a probationary status. Accreditation continues, but generally for a sharply reduced term, and an interim report or extra site visit is generally required.

\section{Accrediting Organizations}

Eight regional commissions in six geographic areas cover all parts of the nation and grant total institutional accreditation. These associations are: Commission on Higher Education, Middle States Association of Colleges and Schools, 3624 Market Street, Philadelphia, Pennsylvania 19104 (Delaware, District of Columbia, Maryland, New Jersey, New York, Pennsylvania, Puerto Rico, Virgin Islands), Commission on Institutions of Higher Education, New England Association of Schools and Colleges and Commission on 
Technical and Career Institutions, New England Association of Schools and Colleges, 209 Burlington Road, Bedford, Massachusetts 01730-1433 (Connecticut. Maine, Massachusetts, New Hampshire, Rhode Island, Vermont); Commission on Institutions of Higher Education, North Central Association of Colleges and Schools, 30 N. LaSalle Street, Suite 2400, Chicago, Illinois 60602 (Arizona, Arkansas, Colorado, Illinois, Indiana, Iowa, Kansas, Michigan, Minnesota, Missouri, Nebraska, New Mexico, North Dakota, Ohio, Oklahoma, South Dakota, West Virginia, Wisconsin, Wyoming); Commission on Colleges, Northwest Association of Schools and Colleges, 11130 NE 33rd Place, Suite 120, Bellevue, Washington 98004 (Alaska, Idaho, Montana, Nevada, Oregon, Utah, Washington); Commission on Colleges, Southern Association of Colleges and Schools, 1866 Southern Lane, Decatur, Georgia 30033-4097 (Alabama, Florida, Georgia, Kentucky, Louisiana, Mississippi, North Carolina, South Carolina, Tennessee, Texas, Virginia), Accrediting Commission for Senior Colleges and Universities, Western Association of Schools and Colleges, c/o Mills College, Box 9990, Oakland, California 94613 (American Samoa, California, Guam, Hawaii, Trust Territory of the Pacific); and Accrediting Commission for Community and Junior Colleges, Western Association of Schools and Colleges, 3402 Mendocino Avenue, Santa Rosa, California 95403 (American Samoa, California, Guam, Hawaii, Trust Territory of the Pacific).

Eight associations accredit total institutions on a national scale. These are: Commission on Accreditation, Accrediting Association of Bible Colleges, 5890 S. Semoran Boulevard, Orlando, FL 32822; Board of Commissioners, Accrediting Bureau of Health Education Schools, 2700 South Quincy Street, Suite 210, Arlington, VA 22206; Accrediting Commission for Career Schools/Colleges of Technology, 2101 Wilson Boulevard, Arlington, VA 22201; Accrediting Council for Independent Colleges and Schools, 750 First Street, NE, Suite 980, Washington, DC 20002; Accreditation Commission, Association of Advanced Rabbinical and Talmudic Schools, 175 Fifth Avenue, Suite 711, New York, NY 10010; Commission on Accrediting, The Association of Theological Schools in the United States and Canada, 10 Summit Park Drive, Pittsburgh, PA 15275-1103; Commission on Occupational Education, Council on Occupational Education, 41 Perimeter Center East, NE, Suite 640, Atlanta, GA 30346; and Accrediting Commission, Distance Education and Training Council, 1601 - 18th Street, NW, Washington, DC 20009.

Finally, forty-one national associations offer recognized specialized and professional accreditation for programs or other academic units within an institution, or for free-standing single purpose institutions. It is thus possible that a large number of accrediting bodies may be involved in a single institution, usually a university with a variety of professional programs. However, for most degree-granting institutions, the basic accreditation remains institutional (and usually regional) accreditation upon which virtually all other accreditation is built.

\section{Relationship of Accreditation to the States}

Before the organization of voluntary accrediting associations, state departments of education and state universities were faced with the necessity of judging the quality of the educational programs of collegiate institutions within their states. The statutory responsibilities of the states for licensing public school teachers required the development of systems of state approval of teacher preparation institutions. The Board of Regents of the University of the State of New York was the first state agency to develop machinery for the approval of courses of study in teacher education, as well as in the liberal arts and many other specialized areas. The majority of the state agencies did not begin accrediting until after the first decade of the present century; and to a great extent, they have continued to limit their accrediting activities to approval of teacher education programs.
Accrediting activities by state universities in nearly every instance had their origin in relations with secondary schools. These accrediting activities related to the admission of secondary school graduates to the universities on the basis of certification of he secondary schools rather than entrance examinations given to the applicants. Most of the state universities, however, have abandoned the practice of accrediting other institutions of higher education and now rely upon the accredited status given through the institutional accrediting associations.

\section{The Recognition of Accrediting Bodies}

The Council for Higher Education Accreditation (CHEA) is the successor structure for the nongovernmental recognition of accrediting bodies. It replaces the Council on Postsecondary Accreditation (COPA), which dissolved on December 31, 1993, and its successor, the Commission on Recognition of Postsecondary Accreditation (CORPA) which dissolved on December 31, 1996.

The Council for Higher Education Accreditation (CHEA) is a nonprofit organization of colleges and universities. Established in 1996, CHEA serves as a national advocate for voluntary selfregulation through accreditation. CHEA serves students and their families, colleges and universities, sponsoring bodies, governments, and employers by promoting academic quality through formal recognition of higher education accrediting bodies. CHEA recognizes, coordinates, and periodically reviews the work of its recognized accrediting bodies and the appropriateness of existing or proposed accrediting bodies and their activities through its granting of recognition.

\section{Relationship of Accreditation with the Federal Government}

Although the federal government does not accredit any educational activities, the Veterans Readjustment Act of 1952, which provides for federal assistance to veterans for their education, charged the former United States Commissioner of Education with the responsibility of publishing a list of nationally recognized accrediting agencies, which he determined to be reliable authorities for determining the quality of training offered by educational institutions. In 1968, the Accreditation and Institutional Eligibility Staff and an associated internal advisory committee were established in the United States Office of Education to administer the commissioner's review process for accrediting agencies being used to establish institutional eligibility for several other education acts.

Congressional authorization for federal involvement in nongovernmental accreditation has traditionally been limited to the establishment of an institution's eligibility to apply for funds from federal programs and the maintenance of records of accrediting status by the Secretary of Education to implement the processes of legislation.

\section{The Triad}

As the system presently functions, there is a need for the federal government to establish eligibility for its funds, as there is a need for the states to charter educational institutions within their jurisdictions. The voluntary sector, represented by the accrediting organizations serves as a bridge between the federal and state roles in education.

Thus, a three-part structure for accreditation has been created. This three-part structure has been termed a "triad" for eligibility. The triad consists of the states, which grant institutional charter or licenses to operate; the accrediting bodies, which provide an educational assessment of institutions and programs; and the federal government, which provides funding for some activities related to student aid and education. 


\section{Information on Accredited Institutions and Accreditation}

The American Council on Education annually publishes Accredited Institutions of Postsecondary Education, which can be ordered from Oryx Press, 4041 North Central Avenue, Suite 700, Phoenix, Arizona 85012-3397 (telephone: 1-800-279-6799). Each accrediting body recognized by CHEA publishes a list of accredited institutions or programs.

\section{References}

Astin, Alexander W., Bowen, Howard R., and Chambers, Charles M. Evaluating Educational Quality. Washington, DC: Council on Postsecondary Accreditation, 1979.

Casey, Robert J., and Harris, John W. Accountability in Higher Education. Washington, DC: Council on Postsecondary Accreditation, 1979.

Finkin, Matthew W. Federal Reliance on Educational Accreditation: The Scope of Administrative Discretion. Washington, DC: Council on Postsecondary Accreditation, 1978.
Fisk. Robert S. and Duryea, E.D. Academic Collective Bargaining and Regional Accreditation. Washington, DC: Council on Postsecondary Accreditation, 1980.

Harcleroad, Fred F. Voluntary Organizations in America and the Development of Educational Accreditation. Washington, DC: Council on Postsecondary Accreditation, 1980.

Kaplin, William A. Accrediting Agencies' Legal Responsibilities: In Pursuit of the Public Interest. Washington, DC: Council on Postsecondary Accreditation, 1981.

Kuhns, Eileen and Martorana, S.V. Toward Academic Quality OffCampus: Monitoring Requirements of Institutional Accrediting Bodies and the States for Off-Campus, Military Base, and Study Abroad Programs. Washington, DC: Council on Postsecondary Accreditation, 1984.

Lenn, Marjorie Peace. "The US Accreditation System," Quality Assurance in International Higher Education. The Falmer Press, London and Washington, DC: 1992.

Selden, William K. and Porter, Harry V. Accreditation: Its Purposes and Uses. Washington, DC: Council on Postsecondary Accreditation, 1979. 
